Article received on 23 October 2013

Article accepted on 30 November 2013

UDC

\title{
'SHORT LEXICON' OF DEDICATIONS IN THE HANDWRITTEN LEGACY OF JOSIP SLAVENSKI (1896-1955) IN THE LIBRARY OF THE FACULTY OF MUSIC IN BELGRADE
}

\author{
Milica Gajić \\ University of Arts in Belgrade \\ Faculty of Music, Library
}

\begin{abstract}
The paper presents some aspects of the handwritten legacy of Josip Slavenski, stored in the Library of the Faculty of Music in Belgrade - dedications that the composer wrote by his own hand are collected in one place. These are mainly dedications to musicalperformers - soloists and ensembles. They reveal many biographical details from the author's life - from performances of his works to friendly and professional contacts. Perceiving Josip Slavenski's oeuvre from this aspect calls to mind many associations with the general artistic climate of the age he was living and working in.
\end{abstract}

Key words: Josip Slavenski, dedications, handwritten legacy, Library of the Faculty of Music in Belgrade

Studying the voluminous handwritten legacy of Josip Slavenski, an extremely important composer even on an international scale, largely contributes to the accurate perception of the various developmental stages in his creative path. The thematic list of this legacy, which today is stored in the Library of the Faculty of Music in Belgrade, was done about thirty years ago, in two ways:

* Author contact information: milgaj2002@yahoo.com 
1. Chronological list - which was published as the second volume of the book "Josip Štolcer Slavenski" by musicologist Eva Sedak ${ }^{1}$

2. Genre list - made by a group of enthusiasts, who were putting the legacy of Josip Slavenski in order before it was moved out of the apartment in 33 Sveti Sava Street. ${ }^{2}$

It contains about forty pages of text with detailed descriptions of each of the composer's works, sketches, variants, copies and the author's most important handwritten notes. In essence, it refers to about 180 compositions - from beginner efforts and the oldest sketches to original and autonomous pieces which made Josip Slavenski a creator of international influence and importance. At the same time, these are the works which undoubtedly secure permanent artistic value and greatness. Besides, these handwritten notes offer an plenitude of indisputable evidence that Josip Slavenski was sometimes absorbed, even obsessed, with tremendous, all-consuming preoccupations about the world, humankind, the universe, and with various cultures and civilizations.

Following his handwritten dedications ${ }^{3}$ in autographs, chronologically creates, in our opinion, not only an easy-to-follow catalogue of the works included but also a different perspective of his creativity. This knowledge greatly enriches the pool of data on the diversity and stratification of Josip Slavenski's personal, professional, and even conceptual contacts, as well as the fullness of this artist'slifestyle. For he was so well-informed and had such breadth of vision, regarding both day to day events and the eternal, unsolvable mysteries of humankind, that many today might envy him.

Firstly, the most frequent are dedications to musical performers - soloists and ensembles. The majority of these dedications on the pieces by Josip Slavenski reveal certain details from his professional and private life - from performances of his works to various friendly and professional contacts, but also artistic and moral convictions. Apart from personal and intimate reasons,

\footnotetext{
${ }^{1}$ Eva Sedak, Josip Štolcer Slavenski - skladatelj prijelaza [Josip Štolcer Slavenski - the Composer of Transition] (I, II), Muzički informativni centar i Muzikološki zavod, Zagreb, 1984.

${ }^{2}$ Cf. the text by Professor Mirjana Živković about the history and work on this legacy: "Zaostavština Josipa Slavenskog u Biblioteci Fakulteta muzičke umetnosti u Beogradu" ["Legacy of Josip Slavenski in the Library of the Faculty of Music in Belgrade"], Banja Luka, 2013 (in print).

${ }_{3}^{3}$ Dedication, from Latin dedicare - consecrate, proclaim, affirm, set apart, meaning the act of bestowing something to someone, regardless of whether the gift will be requited. It is mostly used for things, manuscripts of compositions in this case, which the author made personally, including the inscription of dedication.
} 
Gajić, M.: 'Short Lexicon' of Dedications in the Handwritten Legacy ... (147-165)

the composer's dedications are often related to commissions and competitions, but also to the author's personal gratitude after the successful performances of certain works. Josip Slavenski's sincerity, and often even exalted enthusiasm, spontaneously inspired him to dedicate his musical works, as a token of gratitude, mostly to the outstanding performing capabilities of particular soloists and diverse ensembles. Thus we find the names such as the violinist Zlatko Baloković, the conductor Matej Hubad, the choirs Hlahol from Prague, Mladost, Balkan, Lisinski, Tomislav, Obilić...

Let us peruse the legacy and briefly elaborate each of the works that had a purpose other than purely artistic.

The first, and the oldest surviving, composition by Josip Slavenski was written exactly one hundred years ago, in 1913. It is the piece Uspomena iz Varaždina [Souvenir (de Varaždin)] for piano solo. Written before the author's departure to study music in Budapest, this waltz-type miniature by a sixteen-year old composer-to-be bears the following double dedication: "Svečano mojemu učitelju glasovira v. n. g. Dragutinu Simonu kr. Kot. Sudac u Varaždinu. Mojem milom dobročinitelju Ante Stohru ${ }^{5}$ za uspomenu na componista 1913, IX, 3" ["Solemnly to my piano teacher, the esteemed $\mathrm{Mr}$ Dragutin Simon, RoyalCounty Judge in Varaždin. To my dear benefactor Ante Stohr, in memory of the componist, 1913, IX, 3"]. The rear page of the piece reads: "Les adieux et le retour Dolores". The work is supplemented with the author's letter to Ante Šter from Budapest, asking him to modify bars 9-20 of the composition so that "ne bi bila slična K. Leharu" ["it would not resemble K. Lehar"]. It seems that he was the first to realize that such a composition was the fruit of initial, self-taught attempts, in which we find spontaneous and intuitive harmonies.

Igraj kolo [Go to a Round Dance] for piano, from 1914/1915. The autograph of this composition is dedicated to Vinko Žganec, with whom the composer was a close and life-long friend - in his own words, "moj Međimurac" ["my man from Međimurje"]. ${ }^{6}$ The title page reads: "Improvizacija na jugoslov-

${ }^{4}$ Dragutin Simon was a judge in Varaždin and a thoroughly educated man. He was also a good musician and choirmaster.

5 Ante Šter, or Stöhr (1847-1923) from Varaždin was a respected and distinguished music teacher, composer, pianist, violinist and music educator, who also established a private music school in Varaždin. He noticed young Josip Štolcer and gave him his first professional musical education. He helped him to apply at the Musical School of the Croatian Musical Institution, but Štolcer's works received negative reviews on that occasion. What Josip Slavenski owed to him was not only the first professional lessons and advice, but also important and unreserved support in his earliest creative efforts.

${ }^{6}$ Vinko Žganec (1890-1976), although a trained lawyer with a long career in the law, he 
enske popevke i igre" ["Improvisation on Yugoslav songs and dances"]. A list of three compositions is added: FROM MEĐIMURJE - copied in Belgrade 1925.

Serenada [Serenade] for string quartet, 1914. This piece was also dedicated to his first music teacher in Varaždin: "Mojemu najmilijem prijatelju vg. A. Stohru Štolcer Međimurec 1896." ["To my dearest friend, the esteemed Mr A. Stohr, Štolcer of Međimurje 1896".

Što bo tebe ljubček troštal, four-part mixed choir, 1915. This work is dedicated to the Glasbena matica Music Society from Ljubljana. ${ }^{7}$ Besides, we can also notice the dedication to the Croatian Choral Society Kolo ${ }^{8}$ Moreover, Slavenski dedicated to Kolo an entire choral cycle titled Pesme moje majke [My Mother's Songs], containing "5 zborova na međimurske narodne pjesme za koje mi je inspiracije ili tekst dala moja majka Julija Novak" ["5 choral pieces on folk poems from Međimurje, for which the inspiration or verses were provided by my mother Julija Novak"].

Voda zvira iz kamena, four-part mixed choir, 1916. This was the first signature work of the young composer which became popular and famous, even a classic. Initially, it was dedicated to the renowned choral society Hlahol from

became a well-known and distinguished ethnomusicologist, melographer and composer. He started collecting and arranging folk tunes from Međimurje as early as secondary school, and later he expanded his melographic activity geographically. His research of Glagolitic chant is also important. Žganec was among the first in these parts of the world who conducted scholarly research and analysis of folk tune structure using contemporary scholarly and scientific methods. The domains and subjects of his research were diverse: from the tonal and modal structure of folk music, to folklore elements in the Catholic and Orthodox liturgical chant, to decasyllabic folk versification.

7 The Glasbena matica Music Society from Ljubljana was established in 1872, at the initiative of Vojtech Valenta, and soon they started to publish their own musical editions. Almost all Slovenian composers collaborated with the Society; hence it has played an important role in the development of Slovenian music. In 1882, they established their Music School, which in 1919 became the Conservatory. As early as in 1891 they formed a choir which, with Matej Hubad as the choirmaster, achieved a great performance quality, forcefully inspiring the development of domestic creativity in choral music.

${ }^{8}$ It was established in 1862 in Zagreb, under the slogan Tko pjeva - zlo ne misli [He who sings, thinks no evil], and its main goal was to nurture Croatian music. However, it was not before 1912 that their amateur orchestra was founded. As other similar ensembles of the kind, they had several crises in their history - they were cancelled, re-established, joined with other ensembles... Apart from important domestic and foreign choral pieces, they also performed larger vocal-instrumental works. They cultivated their publishing activity, and they also initiated the foundation of the Croatian Choral Union. As an important fact, it should be mentioned that Kolo bought up Vatroslav Lisinski's manuscripts. 
Gajić, M.: 'Short Lexicon' of Dedications in the Handwritten Legacy ... (147-165)

Prague. ${ }^{9}$ The choir gave the premiere performance in Prague, on $22^{\text {nd }}$ May $1922 .{ }^{10}$

Sa Balkana [From the Balkan], suite for piano solo, 1917. The autograph contains dedications to two notable pianists of his time: Alexander Borovsky ${ }^{11}$ - the $1^{\text {st }}$ and the $3^{\text {rd }}$ movements; and Nikolai Orlov ${ }^{12}-$ the $2^{\text {nd }}$ and the $4^{\text {th }}$ movements.

Fuga [Fugue] in the form of a symphonic poem, for large orchestra, 1917 (see Ex. 1). There are two identical copies of this work in Josip Slavenski's legacy, bearing different dates and places of origin: Ploieşti 1917 and Čakovec 1920. This work for a big post-Romantic symphonic orchestra is dedicated to his teacher of musical forms and counterpoint, Victor von Herzfeld, ${ }^{13}$ in the second year of his studies at the Budapest Conservatory. It was one of the rare works that the author later repudiated. He personally wrote this: "Ova Fuga je jedan eksperiment u duhu evropske muzike te zabranjujem ovo delo za izvođenje javno: iz tih razloga ne priznajem ovo delo za izvođenje javno. Josip Slavenski 1939." ["This Fugue is an experiment in the spirit of European music and so I forbid this work to be publicly performed: for these reasons, I do not acknowledge this work for public performances. Josip Slavenski 1939"].

Nokturno [Nocturne] for orchestra, 1917 (see Ex. 2). The dedication on this work reads: "A Monsieur Dr. Hugo pl. Michalovich". This is Hugo Mihalović, a well-known pianist at the time, who whole-heartedly helped Slavenski in his admission to the Budapest Conservatory. Besides, the title page of the compo-

\footnotetext{
9 The famed and popular Hlahol choir, a choral society from Prague, first appeared in public on $4^{\text {th }}$ January 1861 , as a male choir, but in time they became a mixed ensemble. The programmes and interpretations always depended on the current choirmaster. At the time when Josip Slavenski wrote Voda zvira, it was Jaromír Herle, who achieved outstanding professional and artistic results with the choir, won international prizes and held great international tours. They visited Yugoslavia in 1932.

${ }^{10}$ Cf. Milica Gajić, "Praške godine Josipa Slavenskog (1920-1923)" ["The Prague Period of Josip Slavenski (1920-1923)"], Međimurje, Čakovec, 1985, 7, 109-115.

${ }^{11}$ Alexander Borovsky (1889-1968) was a Russian pianist who studied piano at the Petrograd Conservatory. He emigrated in 1920 and gave concerts all over Europe, North and South America. From 1941 he lived in the USA, and in 1956 he became a professor at the Boston University. His repertoire was broad and diverse, and he left behind a great number of recordings, particularly of Bach's works.

12 Nikolai Andreyevich Orlov (1892-1964), Russian pianist. He studied piano and composing at the Moscow Conservatory, where he later worked as a professor. From 1922, he lived in Paris and gave concerts all over the world. He spent his last years in Scotland.

13 Victor von Herzfeld (1856-1920), a violinist and composer, studied music in Vienna. After spending time in Berlin, from 1886 he worked in Budapest, as a professor at the Conservatory and the second violinist in the Hubay-Popper Quartet.
} 
sition's autograph bears an author's note: "Simfonijska muzika je veće objavljenje negoli svaka religija i filozofija. Betoven Štolcer." ["Symphonic music is a greater revelation than any religion or philosophy. Beethoven Štolcer"]. Although Nokturno is an early symphonic piece, it shows to a great extent the composer's preoccupations and talent, which fully developed later, and it is considered to be one of the pinnacles of Josip Slavenski's first creative period. Besides, the great success of this piece performed by the Zagreb Philharmonics in 1920 brought enough financial means for him to fulfil his great desire - to go and study music at the Prague Conservatory.

Tri tičice, improvisations on Yugoslav folk songs, for mezzo-soprano and piano, 1918. The author's copy is marked "Zagreb, 5. III 1924", and the title page bears a dedication to Maja Strozzi, ${ }^{14}$ soprano, and Bela Pečić, her husband and accompanist.

Radnička pesma [Workers'Song], for mixed choir, 1918. Dedicated to Ernest Krajanski, ${ }^{15}$ a friend from Varaždin who was a lawyer, but also a musician working as the choirmaster of the Tomislav Choral Society from Varaždin. Krajanski was a life-long driving force and support to Josip Slavenski, hispronounced thirst for knowledge and determination to persist with his education. As a broadly educated man with a sound knowledge of music, he was thrilled by the compositions shown to him by the young composer at the time.

${ }^{14}$ Maja Strozzi-Pečić (1892-1962), coloratura soprano, occupies a place of honour among the artists from this part of the world. Apart from engagements in the Graz and Zagreb opera houses, she also had a concert career as an excellent interpreter of songs. She performed songs by Yugoslav authors on her many tours, thus greatly contributing to the development and recognition of Yugoslav vocal music in the country and abroad. Her husband, Bela Pečić (1878-1938), was a graduated pharmacist, but in time he developed into a competent accompanist. Their concerts in Zagreb - famous Matinées and Musical Soirées - mostly featured the works of Slavonic composers. As a point of interest, Igor Stravinsky dedicated four of his works to Maja Strozzi.

${ }^{15}$ Dr Ernest Krajanski (1885-1941), a lawyer, was an excellent musician who, besides graduating from a law school in Vienna, also studied music with Josef Max. A singer and violinist, but also the choirmaster of the Tomislav Choral Society in Varaždin. His harmonisations of folk songs have survived, and he published texts about music in the local newspaper and the journal of the St. Cecilia Academy. He was murdered in the concentration camp in Stara Gradiška in 1941. Concert programmes of the Tomislav Society "pokazuju, kako je njegov dirigent E. Krajanski finim ukusom odabirao djela starih majstora i modernih naših domaćih skladatelja koji su društvu posvećivali svoje skladbe za pravo prvih izvedbi" ["show that their conductor, E. Krajanski, has tastefully chosen the works of old masters and our modern composers who have dedicated their compositions to the Society, giving the first performances"]. Krešimir Filić, Glazbeni život Varaždina: Muzička škola Varaždin[Music Life in Varaždin: Music School in Varaždin], 1972, 472-474. 
Gajić, M.: 'Short Lexicon' of Dedications in the Handwritten Legacy ... (147-165)

Jugoslovenska svita [Yugoslav Suite], the third suite for piano solo, was finished in Prague on $15^{\text {th }}$ May 1921. It is dedicated to Slovenian pianist Ciril Ličar, ${ }^{16}$ who premiered the work in Zagreb, on $9^{\text {th }}$ May 1922. He was a close friend and collaborator of Slavenski's. Like Slavenski and Tkalčić, he moved to Belgrade to work at the Music School, in response to an invitation from Jovan Zorko, the principal. He was a very interesting musical artist and teacher, as well as an ambitious and active participant in the restoration of the music life in Belgrade.

Ljubica ljubezna/Ružica rumena, four-part mixed choir from 1921, the fourth work in the choral cycle Pesme moje majke. Originally it was dedicated to the Tomislav Choir from Varaždin, ${ }^{17}$ and then to the Lisinski Choir from Zagreb. ${ }^{18}$

De si bila ružica rumena, eight-part mixed choir, 1921. It also belongs to Pesme moje majke, as the third song in the cycle. It is dedicated to the Kolo Choral Society from Zagreb, ${ }^{19}$ who gave the premiere performance in Zagreb in 1923, with Oskar Smodek as the choirmaster.

Sastali se čapljanski Tatari, for mixed or male choir, 1922, dedicated to the Obilić Choral Society from Belgrade.

Romarska popevka, for three-part female choir, is dedicated to the Lisinski Choral Society from Zagreb. The manuscript of this composition contains notation for non-tempered singing and a note with the polyrhythms of indigenous peoples.

\footnotetext{
${ }^{16}$ Ciril Ličar (1894-1957), Slovenian pianist, studied piano in Ljubljana and at the Prague Conservatory (1912-1917) with Professor Hofmeister. First, he was a piano teacher in Zagreb, at the Secondary School of the Music Academy, between 1921 and 1925. After moving to Belgrade, he first worked in the Music School and then, from 1937, at the newly founded Music Academy. After graduation, he frequently toured as a refined and reliable accompanist to renowned artists, including Zlatko Baloković, Jaroslav Kocian, Jan Kubelik, Jure Tkalčić, Josip Rijavec. Ličar's most important activity, which he also personally favoured, was chamber music - first he had a trio in Zagreb, with V. Huml and J. Tkalčić. Later, in Belgrade, in 1925, he became a member of the Belgrade Quartet, with the violinists Marija Mihajlović and Jovan Zorko and the violoncellist Jure Tkalčić. He also worked with the pianist Milica Moč from Novi Sad.

17 The Tomislav Choral Society from Varaždin, cf. Footnote 15.

${ }^{18}$ Lisinski was a Croatian choral society established in 1910 in Zagreb, which soon developed into the best choir in Croatia, with a rich and diverse vocal and vocal-instrumental repertoire. They gave a host of concerts not only in Zagreb, but in cities all over the country and abroad. They achieved their highest artistic results in between the two world wars, when they contributed significantly to the development of Yugoslav choral music.
}

19 Cf. Footnote 8. 
Iz Jugoslavije [From Yugoslavia], piano suite, 1923. It is dedicated to $\mathrm{Dr}$ Ivan N. Novak, benefactor and patron of the arts from Varaždin. ${ }^{20}$

Gudački kvartet br. 1 [String Quartet No. 1], Op. 3, 1923, is in fact his graduation work at the Prague Conservatory, under the mentorship of Josef Suk. The note in Cyrillic script can be found in the variant B of the Quartet, and reads: "U Pragu dne 1. maja 1923. izveden 26. juna 1923. Ovo delo je posvećeno Kvartetu op. 133 L. v. Betovena, preciznije veličanstvenoj Betovenovoj Fugi op. 133." ["In Prague, $1^{\text {st }}$ May 1923, performed on $26^{\text {th }}$ June 1923. This work is dedicated to the Quartet Op. 133 by L. V. Beethoven, more precisely to Beethoven's magnificent Fugue Op. 133"]. In this way, the author symbolically expressed his admiration for the unparalleled master of string quartet. This quartet was Slavenski'sfirst work that earned him international recognition and paved the way for his international career. First, with the foregoing performance of the work, which ended his music studies in Prague, in June 1923 at the Prague Conservatory; in October of the same year, when Zagrebački kvartet [The Zagreb Quartet] performed the piece in Zagreb; and most importantly, when the same ensemble played the composition at a gala concert at the Donaueschingen Festival the following year. And in the jury, who accepted its performance at the event, were Busoni, Schönberg, Schreker...

Sonata for piano, Op. 4, 1924. Slavenski dedicated his Sonata for piano to the pianist Svetislav Stančić, ${ }^{21}$ who also gave the first performance on $25^{\text {th }}$ February 1927 in Zagreb. The legacy contains the sketches of this work, done in pencil, 22 pages altogether. There are harmonisations of given melodies on one of the pages, and two songs for two-part male choir on another - harmonisations of songs Uzo deda svog unuka and Još ni jedan zagorec. Besides, the cover page of the Preludium from the Sonata exists, bearing the dedication to Božidar Kunc, ${ }^{22}$ a student of Svetislav Stančić who lived and worked in New

\footnotetext{
${ }^{20}$ Krešimir Filić, op. cit.

${ }^{21}$ Svetislav Stančić (1895-1970), a versatile piano teacher and pianist, was educated in Zagreb and took private lessons in piano and composing in Berlin. He was the first concert pianist in Croatia, and then a professor and the head of the piano department at the Music Academy in Zagreb for a long time, until 1965. He developed into the most distinguished Yugoslav artist and piano educator, and he was mentor to a number of generations of students, having an individual educational approach to each of them. He received numerous prizes and awards, and he was a full member of the Yugoslav Academy of Sciences and Arts and a corresponding member of the Serbian Academy of Sciences and Arts.

${ }^{22}$ Božidar Kunc (1903-1964), a composer and pianist, graduated in Zagreb, studying piano with Svetislav Stančić and composing with Blagoje Bersa. He gave concerts promoting domestic literature for piano, and he ran the Opera Studio at the Music Academy in Zagreb. Since 1951 he lived and worked in the USA.
} 
Gajić, M.: 'Short Lexicon' of Dedications in the Handwritten Legacy ... (147-165)

York City. It is interesting that he, like Josip Slavenski, dedicated his Concert for Violin and Orchestra (1954) to the famous violinist Zlatko Baloković.

Slavenska sonata [Slavonic Sonata], Op. 5, for violin and piano, 1924. It is dedicated to the distinguished violinist Zlatko Baloković. ${ }^{23}$ This gesture "može se smatrati mladenačkom ambicioznošću, kao pogled miša na slona ili želja žabe da postigne veličinu vola iz basne. Na to svatko ima pravo i to nitko nikome ne treba zamjeravati... U odnosu između Balokovića i Štolcera očito nije bilo dvojbe: Štolcerovu posvetu Baloković je prihvatio, ali ne samo kao gestu dobrohotne podrške mladom i perspektivnom talentu. On je sa svoje strane pokazao nesumnjivo priznanje već visokoj kompozitorovoj zrelosti čovjeka koji je tek na pragu svoje umjetničke karijere." ["can be considered a youthful ambition, like a mouse's gaze upon an elephant, or the proverbial frog's desire to attain the size of the ox. Everybody is entitled to that and it should be held against no one... The relationship between Baloković and Štolcer obviously left no room for doubt: Baloković accepted Štolcer's dedication, but not only in a gesture of benevolent support to the young and promising talent. For his part, he showed an unmistakable respect for the creative maturity of a composer who was still on the verge of his artistic career"]. ${ }^{24}$ Although a relatively early work, written at the same time as Sonata for piano, Sonata religiosa for violin and piano and the First String Quartet, the power of its musical expression is overwhelming. It is a one-movement work of complex and multi-layered form - "Big in Small", as people said. Although this composition was also dedicated to Zlatko Baloković, the Zagreb premiere was performed by Francis Aranyi, a member of the Zagreb Quartet.

Nikad [Never], four-part mixed choir, 1924, after the verses of Zvonko Milković. It is dedicated to the Zora Choral Society from Karlovac ${ }^{25}$, and today

${ }^{23}$ Zlatko Baloković (1895-1965), a world-renowned violinist, also called 'a violin genius'. A student of the notable Czech teacher Vaclav Huml in Zagreb, he took master classes with Otakar Ševčík in Vienna. After that, he developed an international concert career, appearing in concert halls in cities all over the world. He settled in New York City and developed a rich social and artistic life. As a friend of Nikola Tesla, he played at his funeral in 1943 - first, Schubert's Ave Maria, and then a folk song Tamo daleko. All the while, besides his artistic engagements, he was a selfless humanitarian, especially during the world wars. He participated in charity concerts for the benefit of the International Red Cross, and later he was the chairman of the Society of Friends of the New Yugoslavia in the USA. Cf. Vladimir Kapun, "Zlatko Baloković prvi put u Međimurju"["Zlatko Baloković for the First Time in Međimurje"], Međimurje, Čakovec, 1986, 147-160.

${ }^{24}$ Cf. Vladimir Kapun, op. cit., 156-157.

${ }^{25}$ Zora was the first Croatian choral society, established in 1858 in Karlovac. It played an important role in the history, culture and art of the region. Apart from concerts and entertain- 
all that exists is a lithograph of this work published by the Society.The work is a variation on Mladost, more precisely a section of four songs which, both in poetry and music, deal with the subject of love. The verses were written by the poet Zvonko Milković, the composer's friend from Varaždin, and this work, in a way, demonstrates the close and affectionate cooperation of the two young friends.

Iz Srbije [From Serbia], suite for piano, 1925. The handwritten dedication reads: "Za Danicu Dimić prepisao sam autor u znak dubokog poštovanja, u Parizu dne 29. 5. 1926." ["For Danica Dimić, copied by the author personally, as a sign of deep respect, in Paris, on 29th May 1926"]. The recipient was the pianist Danica Dimić, almost forgotten today.

Jugoslovenska pesma i igra [Yugoslav Song and Dance], for violin and piano, 1925. One autograph of this work is dedicated to the violinist Mr. Jovan Zorko, ${ }^{26}$ the principal of the Music School in Belgrade, which today is the Mokranjac Music School. At his invitation and intervention, Josip Slavenski moved to Belgrade, as well as some other young educated musicians, because it was Zorko's ambition to gather the most distinguished colleagues in his school. This was yet another occasion where Slavenski entrusted one and the same work to different performing ensembles. Thus, this composition was also rewritten for violoncello, the autograph bearing the date $5^{\text {th }}$ March 1942. The current version was dedicated to Marija Đermanović, the author's marriage witness, and her husband, great friends of Josip Slavenski and his wife Milana. Slavenski composed or rearranged some of his trios in order to be performed at chamber music sessions, which they frequently organized at home.

Sa sela [From the Country], quintet for flute, clarinet, violin, viola and double bass, Op. 6, 1925. The dedication reads: "Dedie a Mahomet fondateur d L Islam en temoignage de profonde admiration" ["Dedicated to Muhammad, founder of Islam, as a testimony of profound admiration"]. We could not find out what the reasons were for such a dedication on the cover page of this composition.

Mladost [Youth], symphonic picture for orchestra, 1925, is a work dedicated to Matej Hubad (see Ex. 3). ${ }^{27}$ The back page of the work bears the follow-

ment, this society organized amateur theatre shows. It was most active after the First World War, achieving its highest artistic results at that time.

26 Jovan Zorko (1881-1942), a violinist and music teacher. He studied violin in Moscow. First he taught music in the seminary, the normal school and secondary schools in Belgrade, and from 1922 to 1942 he was the teacher of violin and chamber music at the Music School. Besides, he was the choirmaster of several choral societies. He was a member of chamber ensembles, the most notable of which was the Belgrade Quartet. He also was a music critic, the author of many compositions and of the textbook Škola za violinu [Violin School].

27 Matej Hubad (1866-1937), Slovenian singing teacher and choirmaster, studied at the Vienna Conservatory. He was a teacher at the School of Glasbena matica, and later a teacher 
Gajić, M.: 'Short Lexicon' of Dedications in the Handwritten Legacy ... (147-165)

ing note by the author: "Veliki učitelj slovenačkih muzičara Matej Hubad bio je jedan od najboljih interpretatora moje vokalne muzike. Po njegovoj želji sam instrumentirao te moje horske kompozicije iz mladosti. Ali tokom instrumentacije usled harmonskog i melodijskog produbljenja međuvremeno su nastale nove simfonijske slike te sa blagodarnošću sam posvetio to delo Matej Hubadu kompozitoru i organizatoru slovenačkog muzičkog života. Josip Š. Slavenski, Beograd 11. maja 1925. god." ["The great teacher of Slovenian musicians, Matej Hubad, was one of the best interpreters of my vocal music. By his wish, I instrumented these choral compositions I had written in my youth. But during the instrumentation, due to harmonic and melodic intensification, new symphonic pictures emerged in the meantime, and so I have gratefully dedicated this work to Matej Hubad, composer and organizer of musical events in Slovenia. Josip Š. Slavenski, Belgrade, $11^{\text {th }}$ May 1925"]. Later, Slavenski rearranged this composition for a much smaller orchestra of string instruments, as the accompaniment, and its task is much more modest - to play an instrumental introduction to every song and to support the choir while singing, but so that the choir nevertheless retains the main role. It is likely that this arrangement was made for a school performance. Once again, it confirms that Josip Slavenski wrote versions of his compositions for diverse ensembles, because he carried several versions of their sound in his inner being.

Ftiček veli da se ženil bude, for four-part female choir with piano accompaniment, 1925. It is dedicated to the Prvo beogradsko pevačko društvo [First Belgrade Choral Society] from Belgrade.

Pesme i igre sa Balkana [Songs and Dances from the Balkan], suite for piano, 1927. The work is dedicated to Milana Ilić, who would later become the composer's wife Milana Slavenski. This composition later became the famous orchestral composition Balkanofonija [Balkanophonia].

Koncert za violinu i orkestar [Concert for Violin and Orchestra], 1927. It is not known if this work was originally unfinished. The title page bears another dedication to the violinist Zlatko Baloković. ${ }^{28}$

of singing and the principal of its Conservatory. From 1923 to 1927 he was the intendant of the National Theatre. As a choirmaster, he attained a high artistic standard with the choir of this institution and influenced the development of the art of choral performance in every way - interpretative and creative.

${ }_{28}$ Zlatko Baloković maintained contact with the Jugoslovenska kulturna matica [Yugoslav Cultural Society] in New York City, whose member was also Aleksandar Savin, and they also collaborated in the Jugoslovensko prosvetno kolo [Yugoslav Educational Circle]. Cf. Sanja Grujić-Vlajnić, "Neki interesantni momenti iz prepiske Josipa Slavenskog" ["Some interesting details from Josip Slavenski's correspondence"], Međimurje, Čakovec, 1988, 111-129. 
Slepačka, for four-part mixed or male choir, 1927. The author's copy, dated $12^{\text {th }}$ June 1932, is dedicated to Kosta P. Manojlović. Among other things, Manojlović wrote a newspaper review of the sevdalinka song Oj slavuju moj during the filming of the movie Fantom Durmitora [Phantom of Durmitor], for which Slavenski wrote the soundtrack. Besides, they were lifelong friends. And when Manojlović became the first Vice-Chancellor of the newly founded Music Academy in Belgrade, Slavenski supported his endeavour to acquire quartertone harmoniums.

Kolo [Round Dance], for two-part female choir and string quintet or string orchestra, 1927 (see Ex. 4). The back page of the work reads: "Narodna svita za violinu i klavir" ["Folklore Suite for Violin and Piano"] (see below), and the piece is dedicated to the Music School in Belgrade. Besides, there is also a separate handwritten violin part, with a dedication to Zlatko Baloković on the cover page, and the list of movements which in Kolo differs from that in Narodna svita. Although Baloković performed Slavenski's compositions on many occasions on his world tours, it seems that he never played Narodna svita, probably because of its modest technical demands.

The Second String Quartet (Lyrical Quartet), Op. 11, 1928. Dedicated to the Zika String Quartet from Prague, who gave the premiere performance at the Frankfurt Radio on $18^{\text {th }}$ April 1929.

Narodna svita [Folklore Suite], for violin and piano, 1932 (cf. Kolo), see Ex. 5. A copy of the violin part survives, with a dedication to Zlatko Baloković, who was active in the Yugoslav Cultural Society in New York City. It is based on the soundtrack for the film Fantom Durmitora [Phantom of Durmitor] and "predstavlja kaleidoskopsko nizanje sedam stavova folklorne građe po principu smene 'igranja' i 'pevanja'. Izdvojen od ostalih filmskih numera, u jednom autografu nosi posvetu našem čuvenom violinisti Zlatku Balokoviću" ["presents a kaleidoscopic sequence of seven movements based on folklore, with 'dance' and 'song' taking turns. The material was chosen from among the movie numbers, and the autograph is dedicated to our famous violinist Zlatko Baloković"]. ${ }^{29}$

Nevesto tanka, two folk songs for male choir, 1933. Dedicated to the Gusla Male Choir from Sofia.

Čije je ono devojče, for three-part male choir, 1933. Also dedicated to the Gusla Male Choir from Sofia.

Simfonija Orijenta [Symphony of the Orient], for soloists, choir and orchestra, 1926-1934. (Ex oriente lux.), see Ex. 6. Slavenski called music a super-religion,

${ }^{29}$ Mirjana Živković, "O filmskoj muzici Josipa Slavenskog” [“On Film Music of Josip Slavenski”], Zvuk, Sarajevo, 1982, 4, 41. Also see ex. 5 in Appendix, a fragment of Slavenski's letter to Baloković. 
Gajić, M.: 'Short Lexicon' of Dedications in the Handwritten Legacy ... (147-165)

and besides, this composition bears the author's dedication to the magnificent Missa Solemnis, written by the composer he held in the highest esteem of all - Ludwig van Beethoven. It "predstavlja plod centralnih preokupacija Slavenskove stvaralačke mašte koja ga je začela još u ranoj mladosti da bi ga ostvarila u zrelim godinama" ["represents the result of the main preoccupations of Slavenski's creative imagination, which first appeared in his early youth, only to bear fruit in his mature years"]. ${ }^{30}$ On the back page he wrote: "Često izvođenje ove moje simfonijske kantate opasno je za monopoliste državnih nagrada i položaja svih režima" ["The frequent performance of this symphonic cantata of mine is dangerous for the regular receivers of state prizes and positions in all regimes"].

$O j$, kuli, stage music for the play and to the verses of Louis Aragon, for mixed and speaking choir, piano, flute and narrator, 1937. Dedicated to the Abrašević Choral Society from Belgrade, ${ }^{31}$ and performed on $10^{\text {th }}$ November 1937 in the Abrašević Workers' Chamber. Directed by Pavle Stefanović, the stage design by Lujo Davičo. The Abrašević Choir had about 80 members at the time and was led by Pavle Stefanović. In the autumn of 1937 he engaged the composer Josip Slavenski, the choreographer Lujo Davičo and the pianist Stana Đurić Klajn, together with two anonymous musicians, to perform this ambitious stage-music work, after a social poem by Louis Aragon whose subject was the exploitation of the dockyard labourers in China. ${ }^{32}$

In this summarized presentation of the chronology of Josip Slavenski's works bearing attributed dedications, we also summarized, in a certain way, his creative preoccupations, professional tributes, but also ambitious constructions and obsessive philosophical views. Although very clear and explicit, they never divulge to the full extent the most intimate and subtle relations that were interactively established between the author and the person or thing that merited a gift from our great composer.

Translated by Goran Kapetanović

\footnotetext{
${ }^{30}$ Mirjana Živković, op. cit.

31 Abrašević Workers' Choral Society was established in 1905 in Belgrade, and their entire activity influenced the development of the political and class consciousness of the workers. Besides following workers' manifestations and demonstrations, with obligatory participation in celebrations on every $1^{\text {st }}$ May, Abrašević unambiguously expressed their political views at spectacles, theatre shows and concerts.

${ }^{32}$ Cf. Milica Gajić, "Revolucionarni duh J. Slavenskog" ["Revolutionary spirit of J. Slavenski”], Međimurje, Čakovec, 1989, 139-140.
} 


\section{APPENDICES}

Ex. 1 - Fugue in the form of symphonic poem for large orchestra (1917), title page, dedicated to Victor von Herzfeld

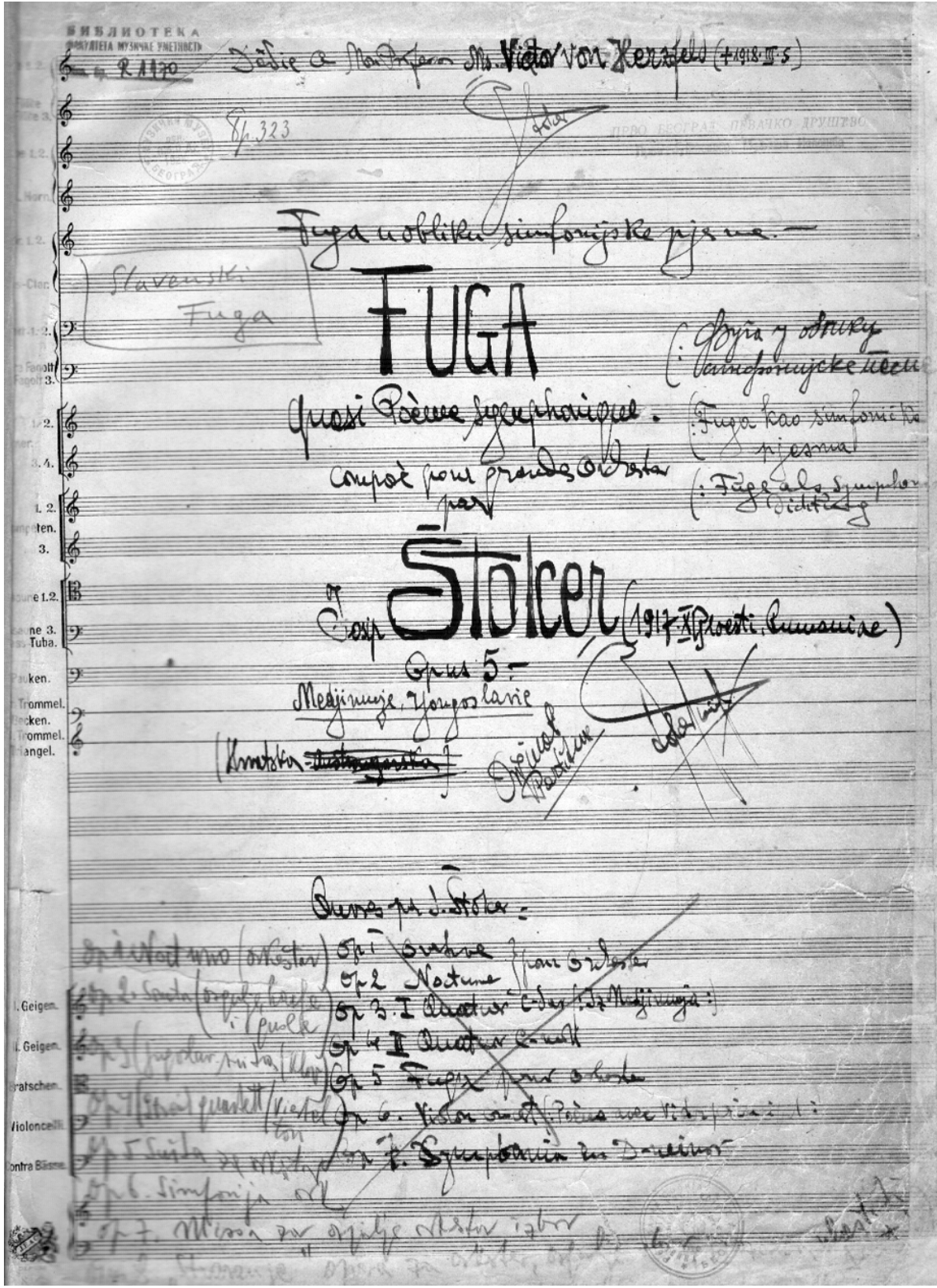


Gajić, M.: 'Short Lexicon' of Dedications in the Handwritten Legacy ... (147-165)

Ex. 2 - Nokturno for orchestra, op. 1 - title page, dedicated to Hugo Mihailović

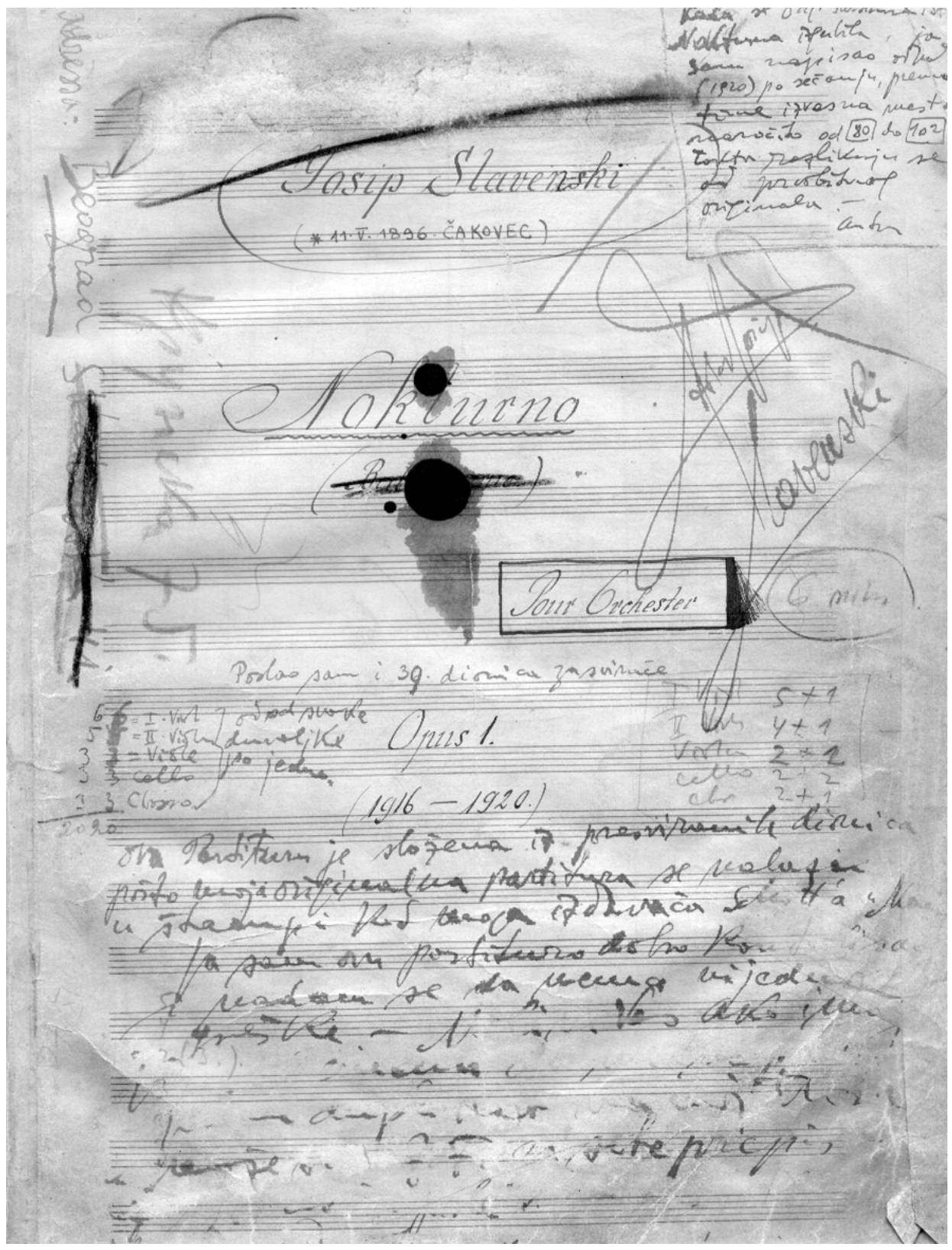


New Sound 42, II/2013

Ex. 3 - Mladost, symphonic picture for orchestra (1927), dedicated to Matej Hubad

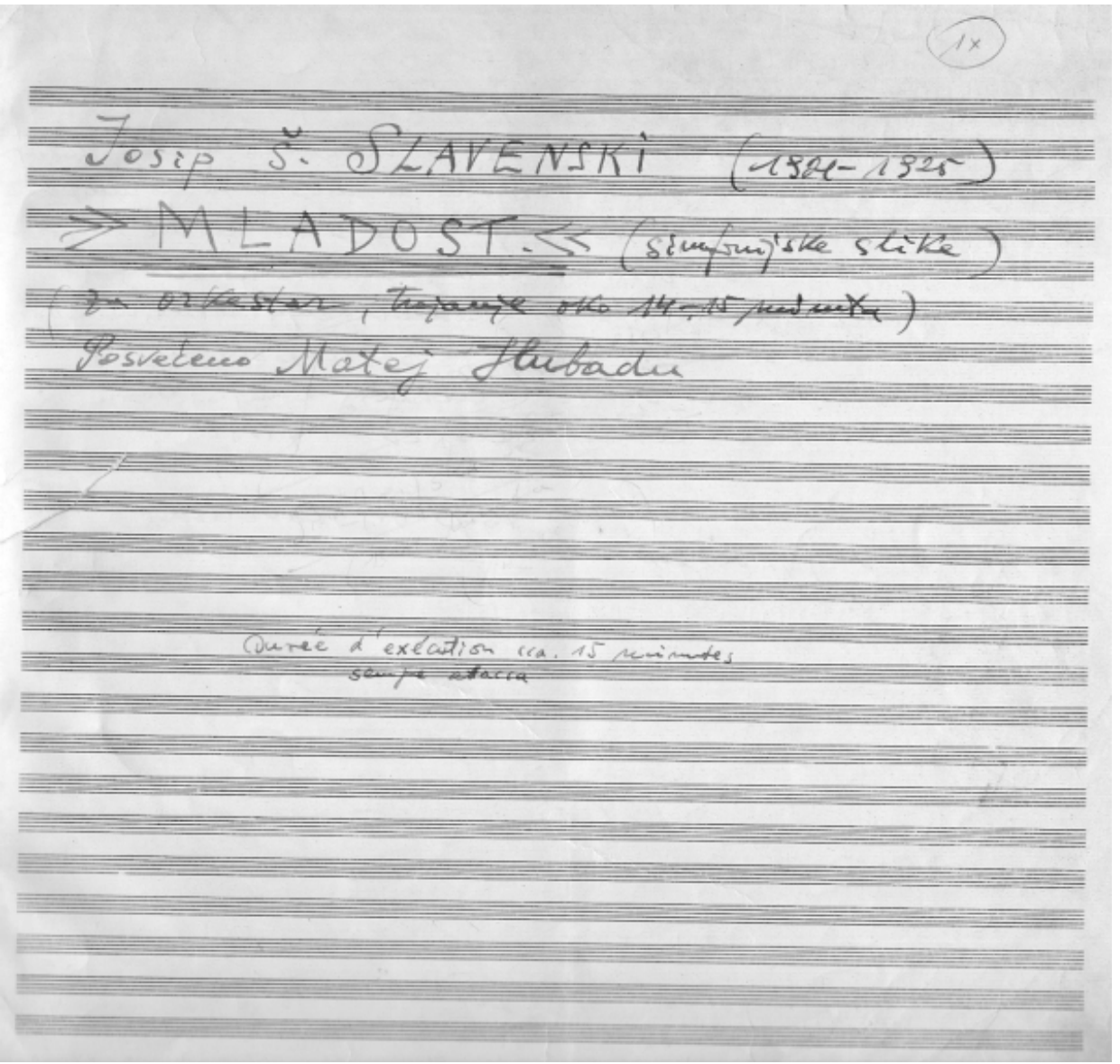





